\title{
NON-SITUATIONAL FUNCTIONS OF DEMONSTRATIVE NOUN PHRASES IN LINGALA (BANTU)
}

\author{
Michael Meeuwis and Koen Stroeken
}

\begin{abstract}
This paper examines the non-situational (i.e., non-exophoric) pragmatic functions of the three adnominal demonstratives, óyo, wâná, and yangó in the Bantu language Lingala. An examination of natural language corpora reveals that, although native-speaker intuitions sanction the use of óyo as an anaphor in demonstrative NPs, this demonstrative is hardly ever used in that role. It also reveals that wâná, which has both situational and discourse-referential capacities, is used more frequently than the exclusively anaphoric demonstrative yangó. It is explained that wâná appears in a wide range of non-coreferential expression types, in coreferential expression types involving low-salience referents, and in coreferential expression types that both involve highly salient referents and include the speaker's desire to signal a shift in the mental representation of the referent towards a pejorative reading. The use of yangó, on the other hand, is only licensed in cases of coreferentiality involving highly salient referents and implying continuation of the same mental representation of the referent. A specific section is devoted to charting the possible grammaticalization paths followed by the demonstratives. Conclusions are drawn for pragmatic theory formation in terms of the relation between form (yangó vs. wâná) and function (coreferentiality vs. non-coreferentiality).
\end{abstract}

Keywords: Demonstratives; Anaphora; Deixis; Bantu languages; Grammaticalization.

\section{Introduction ${ }^{1}$}

Lingala, a Bantu language spoken in Central Africa and classified under Bantu zone C, has three demonstratives, óyo, wâná, and yangó (Meeuwis 2010, in press). ${ }^{2}$ Like other

\footnotetext{
${ }^{1}$ This article is based on talks delivered at "Bantu 3: Third International Conference on Bantu Languages" (March 2009, Tervuren, Belgium) and the "5th Łódź Symposium: New Developments in Linguistic Pragmatics" (May 2010, Łódź, Poland). We wish to thank the participants at these conferences for their useful comments and reactions. We are also grateful to Walter De Mulder and André Motingea for their valuable input.

${ }^{2}$ Tone fulfils a meaning distinguishing role both in the lexicon and in the grammar of Lingala. In this paper, as is customary in linguistic texts on Lingala and other African tonal languages, high tones are marked by means of an acute accent, rising tones with a hacek, falling tones with a circumflex, while low tones are left unmarked. An exception is made for the glossonym 'Lingala', whose tonal pattern is [lingála] but which we leave tone-unmarked for the sake of recognizability. It should also be mentioned that, at least when used as adnominals (see Meeuwis 2010: 81-87 for more detailed information), óyo, wâná, and yangó display no number, noun class, or other type of inflection. This is a result of Lingala's history of pidginization and restructuration (Meeuwis in press), during which a large variety of content and function words that were morphologically variable in the lexifier and adstrate languages were
} 
Bantu languages, Lingala lacks definite and indefinite articles. All three demonstratives occur as adnominals (appearing post-nominally) and pronominals, while only wâná is additionally used as a locative adverbial. In this paper, we wish to focus on the adnominal demonstratives, i.e. on demonstrative determiners in demonstrative noun phrases (NPs) (or 'complex demonstratives' as demonstrative NPs are also called (King 2007; Abbott 2010: 191-194)). We exclude locative adverbials as only wâná reappears in the adverbial paradigm. Our grounds for leaving pronominals out of the discussion pertain not only to our desire to contribute to the understanding of the pragmatic workings of demonstrative NPs in general. There is also a two-fold methodological basis: (i) in Lingala, yangó is homonymous with the third person pronoun for inanimate referents, a situation which is of particular relevance for issues of grammaticalization (see section 5), but which makes it difficult to distinguish, in natural language data, between pronominal demonstrative uses and third person pronoun uses of yangó; (ii) for pronominal óyo, too, word category identifications are rendered problematic, as the same form occurs as a relative pronoun, focus marker, nominative relative marker, and pronominal head in noun phrases (see Meeuwis 2010: chapter 4).

Our focus is further narrowed down to non-situational uses of demonstrative NPs. With the term 'non-situational' (or 'non-exophoric'), we refer to all usage types not involving referents that are visibly present in the physical surroundings of the speech event. There are two reasons why we prefer to use the expression 'non-situational'. First of all, we favour it over 'non-deictic' in order not to preclude notions such as 'discourse deixis' and 'recognitional deixis' (defined in due course), which do not involve referents that can be pointed out visibly. Secondly, we prefer it to 'endophoric', 'anaphoric', and 'discourse-internal' (or 'discourse-referential') since, as will become clear, many but not all usage types attested for the demonstratives under discussion qualify as such (e.g., recognitional deixis), or, at least, debates continue on whether they qualify as anaphora, deixis, or overlapping categories such as 'anadeixis' (Ehrich 1982; Krasavina \& Chiarcos 2007). As we hope to show, the analyses of the non-situational uses of the demonstratives óyo and wâná do not require these latter three conceptual subdivisions; the label 'non-situational' thus presents itself as an adequate and useful superordinate term. The data on yangó do impose invocation of concepts such as 'anaphora', 'coreferential anaphora', and others, all of which we apply, as will also become clear as we move along, in the sense in which they are commonly understood in the literature.

The adnominal demonstratives óyo and wâná can be used both situationally and non-situationally. Óyo is the proximal demonstrative: In situational usage types, it is used to designate referents located close to the speaker ('this X'). Wâná covers both the medial and the distal scopes, i.e. it indicates referents situated close to the hearer or away from both speaker and hearer ('that X'). Yangó is distance-neutral and used for non-situational, in particular anaphoric, purposes only ('aforementioned $\mathrm{X}$ '). ${ }^{3}$

Two research questions are addressed. The first, dealt with in sections 3 and 4, aims at accounting for the differences in pragmatic functioning between yangó on the

petrified, i.e. the agreement-variable prefix was reinterpreted as in inherent part of the lexical root. According to our findings, the morphological petrification of the three demonstratives under study is of no explanatory relevance for their semantics and pragmatics in present-day Lingala.

${ }^{3}$ When used as pronominals, the functional distribution is the same. When used as a locative adverbial, wâná only covers the medial scope. The proximal and distal locative adverbs are áwa and kúná, respectively; neither of them is etymologically related to the demonstratives. 
one hand and non-situational occurrences of óyo and wâná on the other. It will appear that this double (or triple) availability of demonstratives for non-situational reference has led to a distribution of labour in which the functionality of yangó is restricted to cases of anaphora that are coreferential and where the mental representation of the referent is moreover highly activated, while óyo and wâná are employed in a much more extensive variety of coreferential and non-coreferential roles. Against this background, in the concluding section we wish to put into perspective previously made claims according to which the theoretical distinction between coreferential and non-coreferential anaphora cannot be maintained when interpreting natural language data. It seems that, with Lingala, we are confronted with a language whose paradigm of demonstratives does make the distinction quite clearly: A specific form exists - yangóthat is used only as a coreferential anaphor. A second research question (explored in section 5) looks at charting the possible grammaticalization paths followed by the demonstratives. This exercise will prove to be particularly challenging due to the lack of historical data on Lingala. We consider meeting the challenge by consulting available descriptions of cognates in related languages, but, as we will show, these descriptions are not always sufficient, compelling us to qualify our account of the grammaticalization paths of the Lingala demonstratives as tentative.

\section{Starting observations}

The above-mentioned situational functions of óyo and wâná and the uniquely nonsituational capacity of yangó are exemplified in the following three, linguist-constructed, examples.

(1) Alingí kosómba bilambá óyo (pointing gesture).

'He wants to buy these clothes.'

(2) Alingí kosómba bilambá wâná (pointing gesture).

'He wants to buy those clothes (near you or near her/him).'

Lóbí papá na ngái amónákí bilambá mókó ya kitóko penzá. Alingí kosómba bilambá yangó.

'Yesterday my father saw some really nice clothes. He wants to buy these/those clothes.'

As situational reference falls outside the range of functions of yangó, it cannot replace óyo and wâná in (1) and (2). By contrast, in addition to their role as exophoric pointers, óyo and wâná may also be used for non-situational reference. They can therefore well substitute for yangó in (3) to form equally grammatical sentences (while generating added pragmatic meaning, see section 4 below), as is shown in (4) and (5):

(4) Lóbí papá na ngáí amónákí bilambá mókó ya kitóko penzá. Alingí kosómba bilambá óyo.

'Yesterday my father saw some really nice clothes. He wants to buy these clothes.'

Lóbí papá na ngái amónákí bilambá mókó ya kitóko penzá. Alingí kosómba bilambá wâná.

'Yesterday my father saw some really nice clothes. He wants to buy those clothes.' 
However, although native-speaker judgments confirm that oyo is fully grammatical in contexts such as (4), quantitative studies reveal that in actual practice it is not at all frequently used for non-situational reference. Examining a natural language corpus of about 40,000 words for occurrences of óyo, wâná, and yangó (extensive corpora are notoriously difficult to find for African languages), we counted a total of 381 adnominal uses of the three demonstratives. ${ }^{4}$ Distinguishing the situational from the non-situational uses of these adnominal demonstratives, the following distribution obtained (Table 1).

Table 1: Usage types of the adnominal demonstratives in a 40,000 word corpus

\begin{tabular}{|l|c|c|c|}
\hline & Situational & Non-situational & Totals \\
\hline óyo & 80 & 2 & 82 \\
\hline wâná & 83 & 172 & 255 \\
\hline yangó & $/$ & 44 & 44 \\
\hline Totals & 163 & 218 & 381 \\
\hline
\end{tabular}

The low number of adnominal tokens of óyo in non-situational usage (only 2) stands out. The observation that proximal demonstratives are not frequently used for other purposes than situational reference is cross-linguistically compounded (e.g., Diessel 1999: 39; Heine et al. 1991: 179ff). For Lingala, it thus appears that the true 'competition', in terms of potential to be selected by speakers for non-situational reference, holds between wâná and yangó, which is why we eliminate óyo from the discussion from this point forward.

What also stands out is that wâná is used significantly more often than yangó (172 versus 44 occurrences). We are indeed bound to conclude, paradoxically, that although speakers of Lingala have at their disposal an adnominal demonstrative specific for and limited to non-situational reference, namely yangó, it does not dominate this usage type at all. Instead, in this role it is outnumbered by wâná, which otherwise combines the non-situational capacity with a situational one. The analyses in the following sections will seek to interpret these observations.

\section{Coreferentiality vs. non-coreferentiality: yangó for highly salient referents}

The data obtained from the corpora, as well as additional elicitations taken from native speakers, reveal that wâná and yangó are not fully interchangeable. Instead, pragmatic distinctions in terms of the nature and range of the non-situational functions each is able to fulfil appear to motivate a division of labour between the two. The functionality of yangó is limited to cases of strictly coreferential anaphora, i.e. to cases where the referent of the NP in which yangó occurs fully coincides with that of the antecedent. Referential coincidence can be a matter of 'direct' coreferential anaphora, where the noun determined by the demonstrative in the NP is lexically identical with the antecedent, or of 'indirect' coreferential anaphora, in which case another lexeme is used

${ }^{4}$ We hereby would like to acknowledge the great help of Dan Ponsford in compiling and preparing the corpus. The corpus consists entirely of natural, non-elicited data. A small part of the data consists of written texts - most of it is oral and conversational, some of it is oral monologue. 
in the NP but the speaker presents its referent as fully coinciding with the antecedent's (see Vieira et al. 2005: 388, among others). Examples (6) and (7), both taken from the corpus, are illustrations of direct and indirect coreferential anaphora, respectively.

(6) Alors, yé akamátí mbelí ya monéne, kómbó ya mbelí yangó 'líkwangola'. Azwí mbelí na yé ya líkwangola, atîi áwa, abimí.

'So he grabbed a large knife, the name of that knife is 'likwangola'. He grabbed his likwangola knife, he attached it here, and went out.'

(7) A: Après cinq ans atravailler na Madame Fontaine, cinq ans, achanger sikóyo, akómí na Bertrand. Ezá affront, hein. Boyébi que bazalaka opposés.

'After five years that he worked with Mrs. Fontaine, five years, he has changed now, he's gone over to Bertrand. It's an insult, isn't it? You know that they are opposed to one another.'

B: Amílukélí makambo, pé Madame Fontaine moto asímbá náni. Mwásí yangó azalaka na yé très généreuse.

'He's gotten himself into trouble, and Mrs. Fontaine is the one in charge of the thing. That woman is really generous.'

In (6), the demonstrative NP mbeli yangó 'aforementioned knife' reprises the same lexical noun, mbeli ' $\mathrm{knife}$ ', as used in the antecedent mbelí ya monéne 'a large knife'. In (7), the demonstrative NP mwásí yangó 'aforementioned woman' features another noun, mwásí 'woman', than the antecedent it points back to, i.e. Madame Fontaine 'Mrs. Fontaine', but the referents of both the NP and the antecedent are presented as fully coinciding.

Consider, in opposition, the following examples of non-coreferential expressions, i.e. of cases where referent coincidence is absent or imperfect.

(8) A: Ngáí namónaka pé tángo mosúsu, básí óyo tobálaka, bazá lokóla baambassadrices ya bafamilles na bangó epái na bísó.

'I also find that sometimes the women we marry are like the ambassadors of their families to our households.'

B: Namóní ezalaka ndéngé wâná.

'I think it is that way.'

(9) [Baseméki] bakoyina ngáí pó mobáli na ngáí asómbélí ngáí lopángo. Donc bangó, place mbóngo wâná ewútí, eh, bangó bayébí yangó té.

'My sisters-in-law will hate me because my husband has bought me a compound. So, they, where that money comes from, well, they don't know.'

Sentence (8) is a case of 'discourse deixis' (e.g., Cornish 1999; Levinson 2004; Yang 2011), also known as 'abstract anaphora' (e.g., Navarretta 2004; Recasens et al. 2007) or 'impure textual deixis' (Lyons 1977): reference is to an event, state, situation, or idea previously expressed by a non-nominal antecedent, such as a clause, sentence, conversational turn, or larger discourse segment. In this example, the demonstrative NP ndéngé wâná 'that manner' in speaker B's intervention refers to the entirety of speaker A's prior remarks. Sentence (9) exemplifies what in the literature goes under a variety of labels, among which 'associative anaphora' (e.g., Charolles 1990, 1999), 'bridging (cross-reference) anaphora' (Clark 1977; Huang 2000), 'indirect anaphora' (Erkü \& Gundel 1987; Schwarz 2000; Cornish et al. 2005), and 'inferable anaphora' (Prince 
1981; Lui 2004). In this type of non-coreferential expressions, the referent of the demonstrative NP was not explicitly encoded in prior discourse, but can and must be inferred from previously offered material complemented with cultural-stereotypical reasoning. Thus, mbóngo wâná 'that money' is not coreferential with one individually identifiable lexical antecedent. Rather, on the basis of shared sociocultural knowledge, speaker and hearer assume that buying a compound, an event of which the hearer is informed on account of the expression mobáli na ngái asómbélí ngái lopángo 'my husband has bought me a compound', presupposes the possession of money.

Neither in (8) nor in (9) can wâná be replaced by yangó to generate a grammatical sentence.

(10) A: Ngáí namónaka pé tángo mosúsu, básí óyo tobálaka, bazá lokóla baambassadrices ya bafamilles na bangó epái na bísó.

B: Namóní ezalaka ndéngé *yangó.

(11) [Baseméki] bakoyina ngái pó mobáli na ngáí asómbélí ngáí lopángo. Donc bangó, place mbóngo *yangó ewútí, eh, bangó bayébí yangó té.

Thus, although the pragmatic capacity of yangó is limited to non-situational reference, it cannot be employed for every type of non-situational use. The unacceptability of sentences (10) and (11) shows that non-coreferential expression types, such as discourse deixis and associative anaphora, fall outside its realm.

Other non-coreferential expression types that deserve mention, include, first of all, 'metonymic anaphora' (Yamanashi 1994). This type must be considered in close relation to associative anaphora, in that the referent must be inferred from previously offered material on the basis of pars-pro-toto reasoning. 'Recognitional deixis', or briefly 'recognitionality' (Auer 1984; Cleary-Kemp 2007, among others), also referred to as 'memory deixis' (Fraser \& Joly 1980), constitutes a second type. Here, the referent has neither been mentioned at a previous point in the same speech event, nor can it be inferred from material offered at such a previous point. Instead, the speaker assumes he or she and the hearer share a memory of its existence. A third type is 'pure text(ual) deixis' (Lyons 1977; Diessel 1999), where reference is metalinguistic, i.e. the speaker points to the linguistic form of a prior utterance rather than to its proposition. As is the case with discourse deixis and associative anaphora, the use of yangó is not sanctioned for metonymic anaphora (illustrated in 12), recognitional deixis (as in 13), and pure text deixis (as in 14). Instead, wâná (or óyo) must be used.

Lóbí namónákí mótuka ya Jean. Moteur wâná [*yangó] elingí ékúfa.

'Yesterday I saw Jean's car. That engine is going to die soon.'

(13) Nzókandé, l’heure amelaka bakísi na yé wâná [*yangó], aliaka té, amelaka káka míliki, aliaka káka bitabe, esílí, aliaka té.

'Yet, whenever he takes those pills of his, he doesn't eat, he only drinks milk, he only eats small bananas, that's it, he doesn't eat.'

(14) A: [child talking impolitely to his mother]

B: Nalingí elobeli wâná [*yangó] té.

'I don't like that way of talking.' 
In (12), the referent of the demonstrative NP moteur wâna' 'that engine' is to be inferred metonymically from the previously used noun mótuka 'car'. In (13), there is no antecedent for the referent of bakísi na yé wâná 'those pills of his': ${ }^{5}$ its referent is taken to be identifiable via a specific memory the speaker assumes is shared with the hearer. Finally, the mother replying as speaker B in (14) does not refer to the signifié of A's utterance, but to its signifiant, i.e. to the form of language used by the child.

The five types of non-situational reference exemplified here are all instances of non-coreferentiality, whether the involved reference type qualifies, in theory, as anaphora (as in associative and metonymic anaphora), as deixis (as in recognitional and pure text deixis), or as borderline categories. Of more relevance for our purposes than conceptually distinguishing between subtypes of non-coreferentiality is the observation that the use of yangó is not licensed in any of them, and that only wâná (or óyo) is admissible in such contexts. In other words, the role of adnominal yangó in Lingala grammar is firmly limited to that of coreference or 'referent continuation'.

In the following section, we will substantiate this claim in further detail. At this point, it is worth mentioning that in Lingala, a language that lacks the category of articles, yangó shares the function of referent continuation with what in other languages is performed by definite articles. On the basis of a comparative-typological study, Himmelmann, among others, indeed draws attention to the article-like capacity of demonstratives, in languages with no definite articles, to signal "immediate anaphora after first mention" (Himmelmann 1996: 229). However, as we will demonstrate in our discussion of possible paths of grammaticalization below (section 5), a number of observations disallow us to conclude that yangó has already fully developed into a definite article.

\section{Yangó for highly salient referents and wâná in coreferential anaphora}

Our identification of yangó as indicating referent continuation is further supported by the following constraint on its use. Consider fragment (15). The second mention of mái wâná 'that water' is a case of direct coreferential anaphora, i.e. it points back to a lexically identical noun. Yet, native speaker informants insist that yangó cannot take the place of wâná in the second mention.

(15) Avant moto nyónso tout, nyama nyónso ámela mái wâná ifó átúna permission. Sókó olingí komela yangó, ifo ésíla, ékawuka. Sans permission na yé ifó ékawuka. Sikóyo banyama nyónso bayákí, bazalí likita. Bayákí na réunion mókó. Po- Bayákí na réunion, ezalákí fête ya moníngá mókó. Basálaka lokóla ristourne ya banyama: sókí bobomíbobomí nyama- abomí nyama- abomí nyama akeí kotíkela moníngá mosúsu [incomprehensible] nyama. Basálí fête ya banyama. Mokolo mókó bakeí epái ya Tortue. Ezalákí káka yé, káka Kóbá- Moto ya sentinelle akéngelaka mái wâná [*yangó] ezalí Kóbá. Nzoku atíki yé wâná.

'Before anyone at all, any animal can drink from that water, he must ask for permission. If you just want to drink from it [without permission], it should rather get finished, it should rather dry up [than that you drink from it]. Without his permission, it

\footnotetext{
${ }^{5}$ The expression na yé 'of him' is a possessive phrase. When involving pronominal rather than nominal possessors, possessive phrases precede all other adnominals in the NP, including demonstratives (see Meeuwis 2010: 59-62).
} 
should rather dry up. Now, all animals came there, for a get-together. They came for some kind of meeting. Because- They came for a meeting, it was someone's celebration. They had something like a turn-taking scheme for animals: if you've killedyou've killed an animal- someone's killed an animal- he's killed an animal, he has to leave some parts of it for someone else. One day, they went to see the Tortoise. It was just him, just the Tortoise- The sentinel who guards that water is the Tortoise. The Elephant left him there.'

At the point in discourse where the speaker wishes to select an anaphor to re-invoke the referent of the first mention of mái wâná 'that water', the distance with the antecedent is large. There are, moreover, a number of intervening entities possibly hindering the anaphora resolution, such as permission 'permission', likita 'get-together', réunion 'meeting', fête 'celebration', ristourne 'discount scheme', and nyama 'animal'. In other words, the 'activation state' (Gundel et al. 1993), 'accessibility' (Ariel 1990, 1994), 'prominence' (Gordon \& Chan 1995), or 'salience' (i.a., Giora 2003; Ariel 2010: 226) of the mental representation of the referent is low. On account of these conditions, and even though the anaphoric relation is a case of direct coreferential anaphora, yangó cannot be used here. This is in line with yangó's above-mentioned nature as a marker of referent continuation: The use of such markers indeed not only implies coreferentiality, but also high referent salience (Huang 2000; Himmelmann 1996, among others).

What is more, example (15) also reveals that the use of wâná is not limited to non-coreferential expressions, discussed in relation to examples (8)-(14). Wâná appears quite often in coreferential expressions such as the one exemplified in (15). Thus, a first type of conditions under which wâná is preferred to yangó are coreferential anaphoric expressions involving less salient referents. In other words, while yangó fulfils the role of strict referent continuation, one of the effects of the use of wâná, instead, is that of referent enhancement (Gernsbacher 1989; see also van der Wal 2010 for similar findings on demonstratives in Makhuwa). Or, as Cornish would put it, wâná serves to "boost" the referent's salience (2007: 151). Cornish moreover argues that this enhancing or boosting function is "a reflex of the proximal or distal character of the demonstrative" (2007: 151), viz. it is motivated by the basic role of demonstratives such as wâná as situational pointers. Recall that yangó does not share this situational capacity with wâná.

Thus far, we have established that yangó can be used for coreferential anaphora provided that the referent is highly salient, and that wâná is used for non-coreferential expressions as well as for cases of coreferential anaphora where the referent is less salient. But there is more. The data also show that coreferential uses of wâná do not always involve low-salience referents. Consider (16).

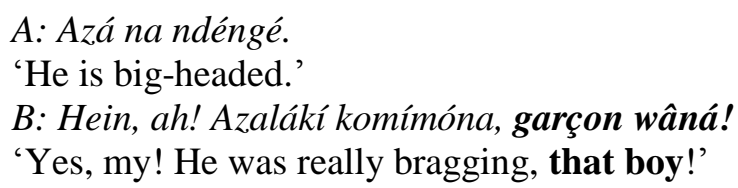

The antecedent in the anaphoric relation is the subject-marking prefix $a$ - on the verbs azá 'he is' and azalákí 'he was': The demonstrative NP garçon wâná 'that boy' points back to that antecedent. As mention of the NP does not occur at great distance from the antecedent, and as there are no interfering candidates possibly hindering the resolution of the anaphoric relation, the referent can be said to be highly salient. Yet, the speaker 
here opts to select wâná rather than yangó as the demonstrative to be used in the NP. By doing so, he or she indicates that the referent of the NP does not fully coincide with that of the antecedent (i.e., that the relation is non-coreferential) and summons the hearer to look for a re-interpretation or requalification of the referent as represented until that point. In this case, the requalification involves the speaker's disapproval of the boy and his demeanour.

For the same reason, when in section 2 we mentioned that it is admissible to replace yangó with wâná in utterance (3) (resulting in (5), here repeated as (17)), this was not intended to imply that the substitution effects no change in pragmatic meaning. Here, the meaning would shift towards an utterance in which the speaker conveys his or her dislike for the clothes in question (also entailing an ironic reading of 'nice clothes' in the antecedent) or his or her doubts as to the usefulness or financial feasibility of buying such clothes.

\section{Lóbí papá na ngái amónákí bilambá mókó ya kitóko penzá. Alingí kosómba bilambá wâná.}

'Yesterday my father saw some really nice clothes. He wants to buy those clothes.'

As a corollary, in cases where it is contextually clear that no disapproval or depreciation is intended, replacing yangó with wâná is infelicitous. Thus, native-speaker informants confirm that, in (7), here repeated as (18), it is problematic to use wâná instead of yangó, as the speaker manifestly holds the real-world referent, Mrs. Fontaine, in high esteem.

(18) A: Après cinq ans atravailler na Madame Fontaine, cinq ans, achanger sikóyo, akómí na Bertrand. Ezá affront, hein. Boyébí que bazalaka opposés.

'After five years that he worked with Mrs. Fontaine, five years, he has changed now, he's gone over to Bertrand. It's an insult, isn't it? You know that they are opposed to one another.'

B: Amílukéli makambo, pé Madame Fontaine moto asímbá náni. Mwásí yangó [??wâná] azalaka na yé très généreuse.

'He's gotten himself into trouble, and Mrs. Fontaine is the one in charge of the thing. That woman is really generous.'

The pejorative connotations resulting from the use of wâná are accounted for by its characterization as a distal demonstrative. Emotional effects of demonstratives have been discussed widely in the literature, under notions such as 'emotional deixis' (Lakoff 1974), 'empathetic deixis' (Lyons 1977: 677), 'metarepresentation' (Nicolle 2007), and others (see De Mulder 2010 [1998] and Apothéloz \& Reichler-Béguelin 1999 for overviews). Our view is that, if proximal and distal demonstratives locate referents in a 'proximal' and 'distal zone', respectively, these 'zones' cannot only be understood in spatial terms, but in terms of affective association/dissociation as well. Using a distal demonstrative such as wâná, the speaker may locate the referent outside his or her personal sphere, in the process emotionally 'distancing' him- or herself from it and thus expressing depreciation.

Key to a single, schematic analysis, able to account for all non-situational usage types of wâná (i.e., its non-coreferential uses, its coreferential uses involving less salient referents, and its coreferential uses involving referents that are salient and that are given a pejorative connotation) is the notion of 'effort'. Three decades ago, Auer already 
mentioned that demonstrative NPs are used for signalling that identifying the intended referent is "potentially problematic" (1984: 636-637). De Mulder argues that, compared to definite NPs, "[t] he demonstrative NP on the contrary urges one to look for a specific referent [...] but this referential procedure costs more effort and must thus be compensated by supplementary interpretative effects" (De Mulder 2010 [1998]: 16). In the same vein, Diessel draws our attention to an interesting parallelism between demonstratives and interrogatives, which "is motivated by similar pragmatic functions: Both types of expressions initiate a search for information" (Diessel 2003: 636). He specifies that "both types of expressions are directives [: t]hey focus the hearer's attention on entities that previously were not activated" (Diessel 2003: 646). These descriptions provide a fitting and adequate identification of what is involved in all possible uses of the adnominal demonstrative wâná in Lingala: With wâná, the speakers indicates that pinpointing which referent they exactly intend, and/or how exactly they intend the hearer to construe it, is not self-evident, but that an effort has to be made in order to identify it correctly.

First of all, when used non-coreferentially, as in discourse deixis, associative anaphora, metonymic anaphora, recognitional deixis, and pure text deixis, wâná signals that the referent of the demonstrative NP in which it figures cannot be mapped perfectly onto that of a nominal antecedent. Identifying the NP's referent involves construing the more abstract, at times vague, referent of a large chunk of discourse (discourse deixis); actively inferring the intended entity from a body of previously offered information on the basis of sociocultural knowledge (associative and metonymic anaphora); scanning memory for an entity which the hearer is supposed to be familiar with (recognitional deixis); or orienting to the metalinguistic levels of previous utterances (pure text deixis). Secondly, the effort required when wâná is used in coreferential expressions with less salient referents pertains to the hearer's obligation to look for the referent at a higher distance in the discourse than expected, and to beware of interfering referent candidates. Third, in the case of referents that are highly salient, the use of wâná instead of the less marked yangó induces the hearer not to continue with the referent as (re)presented until that point, but to actively infer how the speaker wishes to modify or re-qualify the referent's attributes (namely, because of wâná's nature as a distal demonstrative, in pejorative terms). In sum, wâná, in all its usage types, signals that some form of referential discontinuity is involved and that increased mental effort is required in the referential procedure. Yangó, by contrast, and as described above, marks referential continuity, inviting the hearer to interpret the ongoing discourse with the same mental representation of the same topical referents. Or, put differently, yangó is situated 'further up' on the scale of referent salience (or 'accessibility scale', Ariel 1990) as compared to wâná and óyo: It is used for more accessible, more salient referents than the other two.

If, as the authors quoted above argue, the application of effort for solving the referential procedure is a typical mark of demonstratives, and if the use of yangó does not involve such effort, the question can be raised as to whether yangó still qualifies as a demonstrative, or to what extent it does. This question is best addressed by exploring the paths of grammaticalization followed by the three demonstratives. 


\section{Grammaticalization}

Lingala is not unique in having demonstratives, óyo and wâná, that add to their basic role as situational pointing devices the capacity to function as markers of non-situational reference. As Diessel (2003: 646) mentions, the observation that demonstratives are apt to fulfil non-situational functions goes as far back as the early $20^{\text {th }}$ century, and probably earlier. Lingala is not unique either in featuring an adnominal demonstrative, yangó, that can only be used for non-situational reference. Above, we already invoked Himmelmann's remark that, in article-lacking languages, demonstratives are often attested to fulfil the role of immediate anaphors after first mention, i.e. to acquire the capacity to be used for more highly salient referents than the ones demonstratives are typically used for. Similarly, Huang makes the claim that "[1] anguages that lack definiteness markers like the Slavonic ones are expected to resort to demonstratives more freely" (Huang 2000: 255), alluding to the role of demonstratives as markers of referent continuation. Analogously, in his comparative study of demonstratives worldwide, Diessel listed a number of non-Bantu languages possessing uniquely anaphoric demonstratives (1999: 99-103). Uniquely anaphoric demonstratives also occur in a significant minority of the Bantu languages. Out of the total of 234 languages Weier examined for his historical-comparative study of demonstratives in Bantu, 75 feature a demonstrative that can only be employed as an anaphor, not as a situational pointing device (Weier 1985). ${ }^{6}$

The question arises which stage in suggested paths of grammaticalization the three Lingala demonstratives occupy, as well as to what origins they can be traced back. Ever since Greenberg's well-known seminal paper (Greenberg 1978), demonstratives have been the object of a series of grammaticalization studies, which converge on the view that demonstratives may lead, via definite articles, non-generic articles, and pronouns, to the emergence of nominal markers (i.a., Hopper \& Traugott 1993, 2003; Heine \& Kuteva 2002; Heine et al. 1991, 1993; Lehmann 2002 [1982]; Himmelmann 1996, 1997; Diessel 1999, 2006). ${ }^{7}$ Summarizing the findings, here slightly adapted for presentational purposes, we may draw the proposed grammaticalization paths of demonstratives as in Table 2 .

Table 2: Grammaticalization of demonstratives

\begin{tabular}{|l|l|}
\hline Stage 1 & Demonstrative, Situational reference only \\
\hline Stage 2 & Demonstrative, Situational and non-situational reference \\
\hline Stage 3 & Demonstrative, Non-situational reference only \\
\hline Stage $4-5$ & Third person pronoun / Definite article \\
\hline Stage 6 & Non-generic article \\
\hline Stage 7 & Nominal marker \\
\hline
\end{tabular}

${ }^{6}$ To Weier's list, we can add the following Bantu languages for which this is the case and for which grammatical descriptions appeared after 1985: Kisembombo (Kambungama 1994), Kagulu (Petzell 2008), Poto (Motingea 2004), Basaá (Hyman 2003), as well as a series of mutually related languages spoken in the Congolese Ngiri-basin (Motingea 1996b).

${ }^{7}$ Note that Heine and colleagues provide information on a much wider range of categories into which demonstratives have been attested to grammaticalize. For the purposes of our present analysis, however, only the ones mentioned here are relevant. 
Pace Himmelmann (1996: 214) and Cleary-Kemp (2007: 340), most scholars agree that, both ontogenetically and diachronically, the situational capacity of demonstratives is basic (Stage 1), even if synchronically demonstratives may be attested to be used more frequently for non-situational than for situational reference (see also the figures in Table 1 above). In a following development (Stage 2), situational demonstratives may acquire the additional capacity to appear in non-situational, mostly anaphoric, expressions. ${ }^{8}$ Some of these demonstratives subsequently cast off their function as situational pointers, thus serving as anaphors only (Stage 3). After this, they may develop further (Stage 4-5) into (i) definite articles in some languages, (ii) from definite articles into personal pronouns in others, (iii) directly into personal pronouns in still others, or (iv) concomitantly into both in yet other linguistic systems (as has been the case in the history of French, for instance). Stage 6, then, is marked by the development of definite articles into articles encoding both indefinite-specific and definite reference (i.e., what Greenberg 1978 labelled "non-generic"). Finally, stage 7 involves the emergence of nominal markers, such as Bantu noun class prefixes.

The analysis of the pragmatic functions of wâná (and óyo) and yangó offered in sections 3 and 4 above compels us to conclude that the former must be taken to occupy Stage 2 in the grammaticalization path and that the latter is to be situated at least in Stage 3: wâná (and óyo) can be used for both situational and non-situational reference, while yangó can only perform the latter function.

Looking deeper into the functions of yangó in Lingala grammar at large, we are able to specify its diachronic position in more detail. In Lingala, the form yangó does not only occur as an adnominal demonstrative, but also appears as a pronominal demonstrative and as a personal pronoun for non-participant, inanimate referents (the distinction between pronominal demonstratives and personal pronouns thus being mostly undetectable in the interpretation of language data). These uses are illustrated in (19) and (20).

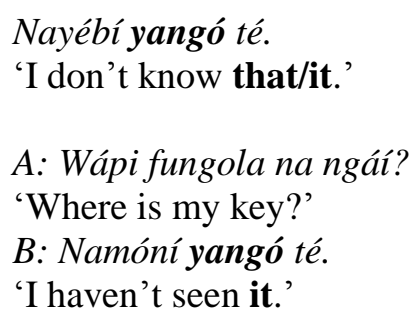

As yangó also serves as a third person pronoun, it can at least be said to have entered Stage 4-5. A second indication to this effect is its above-mentioned article-like behaviour as a tracker of highly salient referents, which is a function typically associated with definite articles (and more attenuated anaphoric expressions) in languages possessing that word category (Huang 2000; Abbott 2010). A third indication is yangó's inability to mark distance contrasts (be they situational or non-situational) in terms of proximity or remoteness, an inability which has also been said to be

\footnotetext{
${ }^{8}$ The grammaticalization from situational to non-situational reference is, in fact, attested in a wider spectrum of word categories than that of demonstratives only (e.g., Traugott 1982; Hopper 1996).
} 
characteristic of definite articles as opposed to demonstratives (Harris 1978; Diessel 1999: 37-38; Himmelmann 1996: 210). ${ }^{9}$

There are, nonetheless, also counter-indications, suggesting that if yangó has entered Stage 4-5, it has done so with one foot only. A considerable number of functions definite articles are typically able to perform (listed by Diessel 1999: 37-8 and Himmelmann 1996: 210; 1997: 36) cannot be taken on by yangó. Yangó cannot be used, for instance, to encode referents at their first mention, but must always be applied anaphorically. It is also excluded from use in NPs that feature (i) generic nouns; ${ }^{10}$ (ii) what Himmelmann (1997: 36) called "unmittelbar-situativer Gebrauch" 'direct situational use', as in Pass me the bucket or Beware of the dog; (iii) what he called "abstrakt-situativer Gebrauch" 'abstract situational use', as in the president, the dean, etc. (1997: 36); (iv) associative anaphora; and (v) the antecedent of a restrictive relative clause. In sum, given, on the one hand, that the demonstrative yangó also serves as a third person pronoun and that it has acquired the article-like capacity of acting as a device for tracking highly salient referents, but, on the other, that it is unable to fulfil a wider array of functions typically associated with definite articles, its most correct positioning on the grammaticalization path is in the transition between Stages 3 and 4-5.

Looking backward on the grammaticalization path, then, the following claims on the origins of Lingala's demonstratives óyo, wâná, and yangó can be made. First of all, while some studies traced the earliest origins of demonstratives back to numeral classifiers (Greenberg 1978: 78), content words (Hopper \& Traugott 1993: 7, 132), or other categories (Heine et al. 1993: 269), Diessel, among others, concludes that "their roots are generally so old that they cannot be traced back to other types of expressions" (2006: 475) and that, depending on their definition, they may be regarded as a universal of human language. Accordingly, we do not wish to venture into hypotheses on the earliest, non-demonstrative origins of óyo, wâná, and yangó. Secondly, then, as regards their history as demonstratives, Guthrie, in his historical-comparative studies of Bantu (Guthrie 1967, 1970), hypothesized that Proto-Bantu had a proximal and a medial situational demonstrative, and that the latter "very soon" came to be used to express "that which has been mentioned" (Guthrie 1970: 247-248). ${ }^{11}$ Applying Guthrie's reconstructions, together with the theories on the grammaticalization of demonstratives in general, to Lingala, it may be suggested that all three demonstratives, óyo, wâná, and yangó, originated as situational pointers only, that each of them later (but not necessarily simultaneously: Proximal óyo probably later than the other two) acquired the additional capacity to signal non-situational reference, and that in a third phase only yangó cast off its role as a situational pointer. As is the case for many Bantu languages, no written historical data older than a hundred years are available for Lingala, which is why hypotheses on the earlier stages of the three demonstratives cannot be tested against records documenting past usage types. Therefore, the only heuristic entry point is offered by looking at cognate demonstratives in related languages.

${ }^{9}$ Diessel (1999: 37-38) adds that the capacity to mark distance is not crucial in distinguishing demonstratives from definite articles, whereas Himmelmann holds on to the criterion more firmly (1996: 210).

${ }^{10}$ Bourquin (1949) showed that in the Bantu language isiXhosa, demonstratives may be used for both first mention and generics.

${ }^{11}$ Meeussen's reconstructions of the grammar of Proto-Bantu differed slightly (1967: 107): His conviction was that in Proto-Bantu the demonstrative in question already performed both the function of a situational pointer and that of an anaphor. 
With regard to óyo and wâná, the language Bobangi, which, as argued by Hulstaert (1989), Samarin (1990), and Meeuwis (2010), represents an older period in the history of Lingala, deserves to be mentioned. According to Whitehead (1899) and MacBeath (1940), Bobangi has inflected forms of the roots -ye (allomorph -yo) and -ná for the proximal and distal demonstratives, respectively, corresponding to óyo and wâná in present-day Lingala. ${ }^{12}$ Whitehead and MacBeath only mention the situational functions of both demonstratives. If their descriptions are complete, it is conceivable that they portray a situation that is of particular relevance for the past of óyo and wâná. One has to bear in mind, however, that their accounts, as those of many of their contemporaries, often lacked the analytic sophistication found in modern grammatical descriptions made by trained linguists. The possibility that they failed to notice the nonsituational functions of the demonstratives should therefore not be excluded. Also pertinent to a historical investigation of wâná are the languages spoken in the Ngiri-basin (see Bokamba 2009, among others, for their relatedness to Lingala), of which Motingea (1996b) offers a detailed historical-comparative study. Motingea mentions that almost all Ngiri-languages, as well as Proto-Ngiri, have -ná as a medial/distal demonstrative used for situational pointing only (1996b: 122-123). Other Lingala-related languages in which a situational, media/distal, demonstrative -ná has been attested include Mabale (Motingea 1996a), Boloki (Motingea 2002), and Iboko (Cambier 1891). But again we wish to make a methodological reservation. These authors consistently approach the studied demonstratives on the basis of functional exclusivity, i.e. they do not envisage the possibility of one and the same demonstrative being used for both situational and non-situational reference, although some of the examples they offer may suggest such double usage.

With regard to yangó, then, quite a number of related languages can be found featuring a cognate whose usage is equally limited to non-situational reference, such as the Ngiri-languages mentioned above (cognate -angó). Languages for which cognates are identified that are employable for both situational and non-situational reference (Stage 2 in the grammaticalization path) include Poto (cognate -angó, Motingea 2004), Libobi (cognate -engú or -mengú, Motingea 1996b), Baloi (cognate -angó, Motingea 1990), and Kusu (cognate -ngu or -ngo, Kahindo 1973), although for the latter language the historical relationship with Lingala is less clear. Regarding Stage 1, in which demonstratives are used as situational pointers only, our attention is drawn by the Ngiri-language Ebuku (cognate -engu, Motingea 1990), as well as by languages of Bantu zone C (to which Lingala also belongs), such as Tetela (cognate -ngo, Weier 1985), Ombo (cognate -ngu, Weier 1985), and Bushoong (cognate -ngó, Weier 1985).

To recapitulate, the available documentation on related languages may offer indications on the three earlier stages of the Lingala demonstratives, i.e. the stage in which wâná and óyo were only employed for situational reference, the stage in which yangó was used both as a situational pointer and for non-situational reference, and the one prior to that, in which yangó was a situational pointer only. The cogency of the documentation, however, rests fully on how complete the provided descriptions are in terms of the range of functions the demonstratives perform.

${ }^{12}$ As mentioned above (note 2), Lingala's history involved the petrification of a large variety of words that were morphologically variable in earlier periods (see Meeuwis 2010). 


\section{Concluding remarks}

Lingala has at its disposal the adnominal demonstrative (or 'demonstrative determiner') yangó, used for non-situational reference only, and two other adnominal demonstratives, óyo and wâná, that are capable of encoding both situational and nonsituational reference. Quantitative evidence on the non-situational occurrences of the three adnominal demonstratives in natural language data reveals that wâná is resorted to about four times more often than yangó (172 versus 44 occurrences). In what precedes, we made an attempt at explaining this imbalance by accounting for the pragmatic differences in functions fulfilled by wâná and yangó. It was demonstrated that adnominal yangó is only used for (direct or indirect) coreferential anaphora involving highly salient referents. The demonstrative wâná may also be used in such contexts, in which case it generates pejorative meanings, while it is additionally employed for coreferential anaphora involving less salient referents, as well as for the wide category of non-coreferential expression types.

One of the theoretical implications to be drawn from the pragmatic distribution of demonstratives in Lingala is that the language makes a comparatively clear formal distinction between coreferential anaphora on the one hand and non-coreferential expression types (be they anaphoric, deictic, or both) on the other. In a critical paper, Apothéloz \& Reichler-Béguelin argued that "there is no clear borderline between coreferential and associative anaphora [i.e.,] that it is impossible to specify the main classes of referring expressions [...] on the basis of the opposition 'associative' vs. 'non-associative' reference", and that "it would be in vain to establish a strict correlation between types of expressions and types of uses" (1999: 367-369; see also Charolles 1990 for similar viewpoints). However valid their claim may be in relation to the specific data they analyzed, we have reasons to dispute its universal validity. It seems that, with Lingala, we are dealing with a language that, as far as the distinction between coreferential and non-coreferential anaphora is concerned, operates a fairly clear-cut one-on-one relation between form and function: yangó is specialized in encoding coreferential anaphora (involving highly salient referents), whereas wâná covers the domain of associative anaphora and other non-coreferential types of expressions.

Interpreting the pragmatic functions of the adnominal demonstratives óyo, wâná, and yangó in terms of paths of grammaticalization proposed in the literature, we hypothesize that óyo and wâná, which in present-day Lingala can still be used both situationally and non-situationally, are less grammaticalized than yangó, which already operates as an anaphor only, presumably having cast off an earlier capacity to function as a situational pointer. A number of characteristics of yangó, such as its distanceneutrality, its appearance as a third person pronoun in other usage contexts, and its capacity to be used for highly salient referents (requiring less effort in identifying the referent than with wâná) indicate that it has already lost some of the recognizable attributes of demonstratives. On the other hand, a range of limitations on its use (e.g., its inability to be employed as generics, in direct situational uses, abstract situational uses, associative anaphora, and with antecedents of restrictive relative clauses) prevent us from conclusively identifying yangó as Lingala's new definite article.

There are no written historical data available for Lingala allowing to test the hypotheses on the origins of the three demonstratives in any certain way. Alternatively, 
we tried to substantiate the hypotheses by invoking information on cognates in related languages. It appears, however, that the corroborating strength of such information is often below par, as in most grammatical descriptions of languages spoken in the region the subject is approached on the basis of functional exclusivity. It seems that a decisive answer to the question whether uniquely situational cognates of óyo and wâná and situational and non-situational cognates of yangó may be found in related languages can be answered only on the basis of detailed field research, including the testing, against native-speaker intuitions, of a variety of demonstrative usage types that is as large as possible. Languages spoken in other parts of the Bantu region, such as the Mozambican language Makhuwa (van der Wal 2010) and the Kenyan language Digo (Nicolle 2007), have recently been submitted to such scrutiny. However, for the Central African languages that are more closely related to Lingala, the invitation to do the same remains open.

\section{References}

Abbott, Barbara (2010) Reference. Oxford: Oxford University Press.

Apothéloz, Denis, and Marie-José Reichler-Béguelin (1999) Interpretations and functions of demonstrative NPs in indirect anaphora. Journal of Pragmatics 31: 363-397.

Ariel, Mira (1990) Accessing noun-phrase antecedents. London: Routledge.

Ariel, Mira (1994) Interpreting anaphoric expressions: A cognitive versus a pragmatic approach. Journal of Linguistics 30: 3-42.

Ariel, Mira (2010) Defining pragmatics. Cambridge: Cambridge University Press.

Auer, Peter (1984) Referential problems in conversation. Journal of Pragmatics 8: 627-648.

Bokamba, Eyamba G. (2009) The spread of Lingala as a lingua franca in the Congo basin. In F. McLaughlin (ed.), The languages of urban Africa. London: Continuum, pp. 50-70.

Bourquin, Walther (1949) The use of the demonstrative pronoun in Xhosa. African Studies 8: 10-19.

Cambier, Emeri (1891) Essai sur la langue congolaise. Brussels: [Imprimerie Polleunis et Ceuterick].

Charolles, Michael (1990) L'anaphore associative: Problèmes de délimitation. Verbum 13: 119-148.

Charolles, Michael (1999) Associative anaphora and its interpretation. Journal of Pragmatics 31: 311326.

Clark, Herbert H. (1977) Bridging. In P.N. Johnson-Laird, and P.C. Wason (eds.), Thinking: Readings in cognitive science. Cambridge: Cambridge University Press, pp. 411-420.

Cleary-Kemp, Jessica (2007) Universal uses of demonstratives: Evidence from four Malayo-Polynesian languages in contact and conflict. Oceanic Linguistics 46: 325-347.

Cornish, Francis (1999) Anaphora, discourse, and understanding: Evidence from English and French. Oxford: Oxford University Press \& International African Institute. 
Cornish, Francis (2007) English demonstratives: Discourse deixis and anaphora, a discourse-pragmatic account. In R.A. Nilsen, N.A.A. Amfo, and K. Borthen (eds.), Interpreting utterances: Pragmatics and its interfaces. Oslo: Novus, pp. 147-166.

Cornish, Francis, Alan Garnham, H. Wind Cowles, Marion Fossard, and Virginie André (2005) Indirect anaphora in English and French: A cross-linguistic study of pronoun resolution. Journal of Memory and Language 52: 363-376.

De Mulder, Walter (2010 [1998]) Anaphora. In J.-O. Östman, and J. Verschueren (eds.), Handbook of pragmatics online. Amsterdam: John Benjamins Publishing Company.

Diessel, Holger (1999) Demonstratives: Form, function, and grammaticalization. Amsterdam: John Benjamins Publishing Company.

Diessel, Holger (2003) The relationship between demonstratives and interrogatives. Studies in Language 27: 635-655.

Diessel, Holger (2006) Demonstratives, joint attention, and the emergence of grammar. Cognitive Linguistics 17: 463-489.

Ehrich, Veronika (1982) Da and the system of spatial deixis in German. In J. Weissenborn, and W. Klein (eds.), Here and there: Cross-linguistic studies on deixis and demonstration. Amsterdam: John Benjamins Publishing Company, pp. 43-63.

Erkü, Feride, and Jeanette K. Gundel (1987) The pragmatics of indirect anaphors. In J. Verschueren, and M. Bertuccelli-Papi (eds.), The pragmatic perspective. Amsterdam: John Benjamins Publishing Company, pp. 533-545.

Fraser, Thomas, and André Joly (1980) Le système de la déixis: Endophore et cohésion discursive en anglais. Modèles Liguistiques 2: 22-49.

Gernsbacher, Morton Ann (1989) Mechanisms that improve referential access. Cognition 32: 99-156.

Giora, Rachel (2003) On our mind: Salience, context, and figurative language. Oxford: Oxford University Press.

Gordon, Peter C., and Davina Chan (1995) Pronouns, passives, and discourse coherence. Journal of Memory and Language 34: 216-231.

Greenberg, Joseph H. (1978) How does a language acquire gender markers. In J.H. Greenberg, C.A. Ferguson, and E.A. Moravcsik (eds.), Universals of human language, volume 3: Word structure. Stanford: Stanford University Press, pp. 48-82.

Gundel, Jeanette K., Nancy Hedberg, and Ron Zacharski (1993) Cognitive status and the form of referring expressions in discourse. Language 69: 274-302.

Guthrie, Malcolm (1967) Comparative Bantu: An introduction to the comparative linguistics and prehistory of the Bantu languages. Westmead: Gregg Press.

Guthrie, Malcolm (1970) Comparative Bantu, 4 volumes. Farnborough: Gregg International.

Harris, Martin (1978) The evolution of French syntax: A comparative approach. London: Longman.

Heine, Bernd, Ulrike Claudi, and Friederike Hünnemeyer (1991) Grammaticalization: A conceptual framework. Chicago: Chicago University Press. 


\section{Michael Meeuwis and Koen Stroeken}

Heine, Bernd, Tom Güldemann, Christa Kilian-Hatz, Donald A. Lessau, Heinz Roberg, Mathias Schladt, and Thomas Stolz (1993) Conceptual shift: A lexicon of grammaticalization processes in African languages. $=$ Afrikanistische Arbeitspapiere 34/35.

Heine, Bernd, and Tania Kuteva (2002) World lexicon of grammaticalization. Cambridge: Cambridge University Press.

Himmelmann, Nikolaus P. (1996) Demonstratives in narrative discourse: A taxonomy of universal uses. In B. Fox (ed.), Studies in anaphora. Amsterdam: John Benjamins Publishing Company, pp. 205-254.

Himmelmann, Nikolaus P. (1997) Deiktikon, Artikel, Nominalphrase: Zur Emergenz syntaktischer Struktur. Tübingen: Niemeyer.

Hopper, Paul J. (1996) Some recent trends in grammaticalization. Annual Review of Anthropology 25: 217-236.

Hopper, Paul J., and Elizabeth C. Traugott (1993) Grammaticalization. Cambridge: Cambridge University Press.

Hopper, Paul J., and Elizabeth C. Traugott (2003) Grammaticalization (second edition). Cambridge: Cambridge University Press.

Huang, Yan (2000) Anaphora: A cross-linguistic approach. Oxford: Oxford University Press.

Hulstaert, Gustaaf (1989) L'origine du lingala. Afrikanistische Arbeitspapiere 17: 81-114.

Hyman, Larry M. (2003) Basaá (A43). In D. Nurse, and G. Philippson (eds.), The Bantu languages. London: Routledge, pp. 257-282.

Kahindo Lufungula, Muhesi (1973) Esquisse grammaticale de la langue kusu. Lubumbashi: Université de Lubumbashi.

Kambungama, Yuka (1994) Les formes pronominales en kisembombo. Annales Aequatoria 15: 269-281.

King, Jeffrey C. (2007) Complex demonstratives, QI uses, and direct reference. Philosophical Review 117: 99-117.

Krasavina, Olga, and Christian Chiarcos (2007) A corpus-based study of demonstratives in German, Russian and English. In M. Davies, P. Rayson, S. Hunston, and P. Danielsson (eds.), Proceedings of the Corpus Linguistics Conference (CL2007), University of Birmingham, UK (27-30 July 2007) http://ucrel.lancs.ac.uk/publications/CL2007/ (last consulted 29 March 2011)

Lakoff, Robin (1974) Remarks on this and that. Proceeding of the Chicago Linguistics Society 10: 345356.

Lehmann, Christian (2002 [1982]) Thoughts on grammaticalization, second edition. Erfurt: Seminar für Sprachwissenschaft der Universität.

Levinson, Stephen C. (2004) Deixis and pragmatics. In L.R. Horn, and G.L. Ward (eds.), The handbook of pragmatics. Oxford: Blackwell, pp. 97-121.

Lui, Lijin (2004) Inferable anaphora reexamined: With special reference to the anaphoric NPs in discourse. Journal of Foreign Languages 5: 28-33.

Lyons, John (1977) Semantics, Vol. 1. Cambridge: Cambridge University Press.

MacBeath, A.G.W. (1940) Bobangi in twenty-one lessons, with exercises \& key. Bolobo: Baptist Missionary Society. 
Meeussen, A.E. (1967) Bantu grammatical reconstructions. Africana Linguistica 3: 79-121.

Meeuwis, Michael (2010) A grammatical overview of Lingála. München: Lincom.

Meeuwis, Michael (in press) Lingala: Survey. In S. Michaelis, P. Maurer, M. Haspelmath, and M. Huber (eds.), Atlas of pidgin and creole language structures, vol. II: The language surveys. Oxford: Oxford University Press.

Motingea Mangulu, André (1990) Parlers riverains de l'entre Ubangi-Zaire. Bamanya: Aequatoria (Etudes Aequatoria 8).

Motingea Mangulu, André (1996a) Eléments de grammaire mabale (Bantou C.30). Afrika und Übersee 79: 203-258.

Motingea Mangulu, André (1996b) Etude comparative des langues ngiri de l'entre Ubangi-Zaire. Leiden: Research School CNWS.

Motingea Mangulu, André (2002) Aspects du boloki de Monsembe: Le ngala de Stapleton. Annales Aequatoria 23: 285-328.

Motingea Mangulu, André (2004) Notes grammaticales et textes poto sur la base de Stapleton (1903) Annales Aequatoria 25: 203-271.

Navarretta, Costanza (2004) Resolving individual and abstract anaphora in texts and dialogues. Proceedings of the 20th international conference on Computational Linguistics, Association for Computational Linguistics Stroudsburg, PA, USA Article 233 (online only). DOI 10.3115/1220355.1220389 (last consulted 29 March 2011)

Nicolle, Steve (2007) Metarepresentational demonstratives in Digo. In R.A. Nilsen, N.A.A. Amfo, and K. Borthen (eds.), Interpreting utterances: Pragmatics and its interfaces. Oslo: Novus, pp. 127-146.

Petzell, Malin (2008) The Kagulu language of Tanzania: Grammar, texts and vocabulary. Köln: Rüdiger Köppe.

Prince, Ellen F. (1981) Toward a taxonomy of given-new information. In P. Cole (ed.), Radical pragmatics. London: Academic Press, pp. 223-255.

Recasens, Marta, M. Antonia Marti, and Mariona Taulé (2007) Text as scene: Discourse deixis and bridging relations. Procesamiento del Lenguaje Natural 39: 205-212.

Samarin, William J. (1990) The origins of Kituba and Lingala. Journal of African languages and Linguistics 12: 47-77.

Schwarz, Monika (2000) Indirekte Anaphern in Texten: Studien zur domänengebundenen Referenz und Kohärenz im Deutschen. Tübingen: Niemeyer.

Traugott, Elizabeth C. (1982) From propositional to textual and expressive meanings: Some semanticpragmatic aspects of grammaticalization. In W.P. Lehmann, and Y. Malkiel (eds.), Perspectives on historical linguistics. Amsterdam: Benjamins Publishing Company, pp. 245-271.

van der Wal, Jenneke (2010) Functions of demonstratives in Makhuwa narratives. Africana Linguistica 16: $183-213$.

Vieira, Renata, Susanne Salmon-Alt, and Caroline Gasperin (2005) Coreference and anaphoric relations of demonstrative noun phrases in multilingual corpus. In A. Branco, T. McEnery, and R. Mitkov (eds.), Anaphora processing: Linguistic, cognitive and computational modelling. Amsterdam: John Benjamins Publishing Company, pp. 385-402. 
Weier, Hans-Ingolf (1985) Basisdemonstrative im Bantu. Hamburg: Helmut Buske.

Whitehead, John (1899) Grammar and dictionary of the Bobangi language: As spoken over a part of the Upper Congo, West Central Africa. London: Baptist Missionary Society \& Kegan Paul.

Yamanashi, Masa-aki (1994) Metonymic anaphora: A cognitive space in natural language. In S. Chiba (ed.), Synchronic and diachronic approaches to language. Tokyo: Liber Press, pp. 577-591.

Yang, Youwen (2011) A cognitive interpretation of discourse deixis. Theory and Practice in Language Studies 1: 128-135.

MICHAEL MEEUWIS is professor of Lingala and African linguistics at the Department of African Languages and Cultures at Ghent University. He has published widely on the grammar and history of Lingala. His recent publications include A Grammatical Overview of Lingala (Lincoln, 2010).

Address: Ghent University, Department of African Languages and Cultures, Rozier 44, B-9000 Ghent, Belgium. E-mail: Michael.Meeuwis@ugent.be

KOEN STROEKEN is professor of anthropology at the Department of African Languages and Cultures at Ghent University. He recently published a monograph entitled Moral Power: The Magic of Witchcraft (Berghahn, 2010), studying the social pragmatics and cultural indexicalities of processes of witchcraft suspicion and accusation in Sukuma-speaking communities (Tanzania).

Address: Ghent University, Department of African Languages and Cultures, Rozier 44, B-9000 Ghent, Belgium. E-mail: Koen.Stroeken@ugent.be 